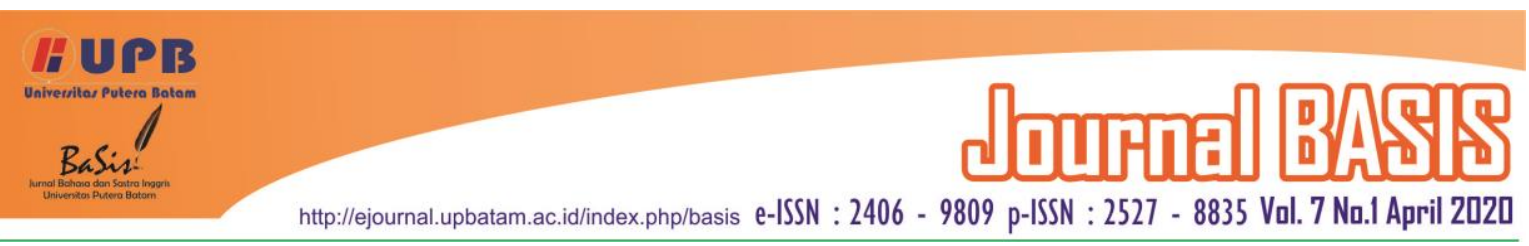

\title{
THE CHARACTERIZATION OF MARGIO IN NOVEL ENTITLED LELAKI HARIMAU BY EKA KURNIAWAN
}

\author{
Ellif Shiffiyn Khairaa \\ University of Airlangga, Surabaya, Indonesia \\ ellif.iffiyn.khairaa-2018@fib.unair.ac.id
}

\begin{abstract}
This researched aims to analyze the characterization of Margio as the main character of the novel entitled Lelaki Harimau by Eka Kurniawan. This study used narrative structure by Gerard Genette which focused on frequency concept to analyze the characterization. The descriptive qualitative method used to reveal and make a deep analysis of the characterization of Margio. The data is taken by reread the novel and written the quotations of the dialogue which focused on the characterization of Margio. The result of this study is Margio has strong characterization and he is the one who connected to the other characters in the novel. He is known as a lovable, obedient to their parents, and a strong man. The moral value of this novel is the key to a perfect family is the good communication of each member of the family. This study is important in how we learned the complexity of human relations, especially in the family.
\end{abstract}

Keywords: Characterization, Frequency, Novel, Lelaki Harimau

\section{INTRODUCTION}

The novel is a literary work which tells about various series of events in the life of the character formed by the author. Lelaki Harimau is one of the novels by Eka Kurniawan which has caught the attention of many readers. Lelaki Harimau got nominated in "The Man Booker International Prize" on March 16 (Edukasi, Kompas.com, 2018). This novel tells a story of a murder in a village where the people still believe in myth and respect the traditions. The setting of the story is supported by a wide choice of characters with strong characterizations. The figures displayed also have a variety of distinctive characters and vary with other characters. The portrayal of a character in this story is formed from a series of events of a story that is episodic and also full of conflict. Therefore, characters and storylines have a relationship with one another.

There are some problematic issues found in this novel. First, the importance of family that represented in the novel. Purwaningsih (2010) the family has a significant role in life so that Indonesian well known as a family person. Family is the first place where we learns norms and tradition that built in family from ages. Therefore, family is the basic foundation of character. The family would not hesitate to help when the other member of family has a problem. This strength of 
family represented in the novel. Lelaki Harimau, represent the family who lived in village with the tradition, norms, and myth in it. The village life which describe intimate of family and closeness between neighbors but arguably. However, this novel gives a complex issues of family that over with murdered.

Second, Lelaki Harimau has a narrative issues that is slow story lines. It means that the author tend to present a long description of events before finally entering the purpose of the story. The choice of words that used is a little difficult to understand. It takes several readings to understand in each episode of the story to finally reveal how the stories and discourses goes in this novel. In the narration the author leads the reader by displaying the interrelation of the characters with one another. It is seen that the author tries to stay focused on the character being told. So that the reader is quite easy in understanding each character that appears in each of the telling. But on the contrary, due to the characters who try to appear in various episodic stories, the storyline in this novel is quite complicated which tends to have a backward flow. Some identical events also appear repeatedly in the story of this novel.

The novel begins with the murder committed by Margio against Anwar Sadat, then the reader is directed to explore the various motives that make the character Margio committed the murder. Some complex motifs and themes try to display in this novel. It is done by conveying conflict and motives is what drives the character to meet with other figures, bring up other conflicts and determine the attitude of other figures. However, behind the various motifs displayed there is the main actor, namely Margio who is the main focus of this story. As the main character, Margio is very fundamental character in the whole subject in the story text. Thus, the construction of the main character is about the commodification of Margio's character to be interesting to study which can then see the meaning behind the story of the novel.

Based on the issues that been discussed, this study focused on a variety of identical events brought by Margio as the main character in Lelaki Harimau by Eka Kurniawan. This study used narrative structure by Gerard Genette by focusing on frequency concept. The main character is going to lead to some significant events of the story so that the characterization can be seen by analyzing the frequency. Therefore, the significant of this study is to help the understanding of the story that focused on the characterization of Margio as he is the one who lead the whole story in some identical events. It can reveal the meaning of the story in Lelaki Harimau' novel by Eka Kurniawan

\section{LITERATURE REVIEW}

2.1. Theory of the Research

Genette (1980) offers five narrative concept; there are order, duration, frequency, mood, and voice. However, this research only used frequency which 
is based on the need for structural analysis to objectify the identical events which leads to the key events of the story. Frequency is a group of similar events based on their similarity. The relationship that occurs between repetition that occurs both in the aspect of events in the story and the narrative in the telling is abstracted into four types, among others;

a) It is told once that an event happened once, formulated with $1 N / 1 S$, for example: yesterday I slept early. This type of frequency is then called the singulative narrative.

b) It is told $n$ times that happened $n$ times, formulated with $n N / n S$, for example: Monday I go to bed early, Tuesday I go to bed early, Wednesday I go to bed early, and so on. This type of frequency is also referred to as a singulative narrative.mention singulative Thisis not related to the amount

c) Mention of both sides (story and discourse), but rather because of the similarity in the number that appears both in terms of story and discourse.

d) It is told $n$ events that happened once, formulated with $n N / 1 S$, for example: yesterday I slept early, yesterday I slept early, yesterday I slept early. This type of frequency is then called the repeating narrative. e. It is told once that an event happened $n$ times, formulated with $1 N / n S$, for example: Monday, Tuesday, Wednesday I slept early. This frequency is here in after referred to as iterative narrative (Genette, 1980)
The identical events is the first step to reveal discourse of the story in Lelaki Harimau and the characterization of Margio as a main character. Nurgiyantoro (2015) the main character is the most told character of the story, either he is the one as a subject of the story or being subject of the story.

\subsection{Previous Studies}

There are some related research of Lelaki Harimau which has been done by some researchers. Gemilang (2016) the influence of the subconscious character of Margio raises conflict in the reality of his life which then raises the existence of defense mechanisms in the face of superego pressure so as to reduce the anxiety experienced by the character. This research only focuses on the psychology of the main character so that it does not present the meaning and ease of reading of this novel. The research used theory from Robert Stanton in the analysis phase which then utilizes Sigmund Freud's theory in the meaning process. Choiriyah (2016) focuses on writing techniques of Eka Kurniawan as novel authors who tend to write fantastic stories. The novels are Lelaki Harimau, Cantik Itu Luka, Dan Seperti Dendam, Rindu Harus Dibayar Tuntas. The research is a reference for researchers in understanding the story telling of the Lelaki Harimau.

Therefore, another study that has same focused on methodologies and reasearch techniques with this study are; Oktavia (2015) discussed the tendency of 
the characterization in novel Bumi Cinta by Habiburrahman El Shirazy. The authors describe character dramatic and analitic. Kobis (2019) used genetic stucturalism to find the characteristic of the society through Jane Eyre and the Great Gatsby novel. It also focused on the impacts of the society of authors' thought in creating those liteary works. Arianto \& Simanjuntak (2019) used ecofeminist apparoach to find the patriarchal stereotypes and paradoxical representation of Mak Ungkai sea ghost story. Those previous studies provide foundation of knowledge and establish similarities and differences of the topic of this study. However, this study is focus on the characterization of Margio as main character of the novel which make this study is important and different with the previous studies.

\section{RESEARCH METHOD}

This study used descriptive qualitative method in formulating the data. Ratna (2008) defined the descriptive qualitative method is a method used by analyzing and describing data. It is used to describe the state of the object under study as the focus of research. The object of the study is novel entitled Lelaki Harimau by Eka Kurniawan.

Data collection techniques were conducted by (1) rereading and write some identical events which lead to the main character of the story in Lelaki Harimau by Eka Kurniawan (2) identification of several identical events in accordance with the concept of the narrative structure by Gerard Genette (3) interpreting and exploring the various identical events related to Margio as the main character. Therefore, the conclusion is done by giving a brief explanation on how the characterization of Margio and reveal the meaning or the moral value in the story.

\section{RESULT AND DISCUSSION}

Character has a significant part of the story. Character bring out the life of the story. Nurgiyantoro said that (2015) the main character is the one most told from the beginning until the end of the story. This study focused on Margio as the main character of the story. Margio is the one who being told since the beginning of the story. Margio is a young man who living in the village and ties with neighborhood. The story begins with the murdered and continue in retracing the steps that led to the crime until find the motive behind the murdered. Therefore, the main story of Lelaki Harimau is murdered committing by Margio against Anwar Sadat. The murdered on the basis of revenge against Anwar Sadat. He tears through Sadat's jugular with his own teeth. Margio confessed the murdered and said calmly that there is a 'tiger' in his body, and blaming that tigers who killed Sadat. From the story, we acknowledge that he is the young man who brave enough to kill Anwar Sadat. All the series of events of the story proved that Margio is the main point of the story. And the strong portrayal of Margio is the point of this discussion.

The discussion below is focused on how the characterization of Margio in the story of Lelaki Harimau's novel by Eka Kurniawan. The discussion begin with 
some identical events that found in the story of Lelaki Harimau. These identical events are parts of events that being told many times in the story. The identical event is found based on the frequency as the concept of Genette's narrative structure. The discussion is begin since his childhood to the day he murdered Anwar Sadat. The childhood stories are background where Margio grown up into the one brave to kill Anwar Sadat.

It is told that Margio's family was not a perfect family. His father always tortured his mother and Margio as well. Since his childhood, he used to watch his mother beaten by his father. At that day, Margio had no power to help his mother or to break up their parent's fight, as mentioned in this quotation;

Sepanjang hidupnya, ia telah sering melihat Komar memukul Nuraeni di depan matanya sendiri, menghajarnya hingga babak-belur. Margio terlampau kecil untuk melerai, dan ia sendiri sering dapat bagiannya pula. Ia hanya berdiri menyandar ke pintu, dengan Mameh di sampingnya menggigit ujung baju, sementara Nuraeni meringkuk di pojok rumah dengan Komar berdiri di depannya, tangan menggenggam rotan penggebuk kasur. Komar selalu punya alasan apa pun untuk mengayunkannya.

Hari Senin itu Margio akan pergi sekolah dengan kaki sedikit terpincang, setelah Komar menggebukinya, dan menenggelamkannya ke bak mandi, dan menjewer kupingnya, dan melemparinya dengan gayung tempurung kelapa. Komar juga sering sirik melihatnya anteng dengan mainan berupa kelereng atau gambar umbul serta jangkrik, dan Margio akan semakin menjadi-jadi jika Komar mengomelinya, membikin Komar habis sabar dan menempeleng Margio. (Kurniawan, 2004, pp. 115117)

The quotation mentioned on how rude his father to his mother and Margio. His father used to beat his mother and him easily without any guilty felt. It seem like his father always has a reason to beat them. His father used rattan and other tools to beat his mother and him. From the time went, Margio dare against his father. However, it only provoked anger of his father that made him beaten more. Margio's parents has a difficult marriage. This portrayal of his family would be the foundation of his characterization this violance became a bad memory of Margio and affects his life. He is growing with full of hatred to his abusive father and confused about his long-suffering mother. However, the violence of his father shaped Margio as an aggressive person. As mentioned in this quotation;

Baginya, kematian Marian melebihi bencana apa pun yang bisa dipikirkannya datang ke rumah mereka, serupa satu pengkhianatan kejam, dan ia tak lagi berkehendak menahan nafsu brutalnya, suatu nafsu yang seringkali dilampiaskannya sedikit pada bokong babi di musim perburuan. Ia akan melihat bokong itu menjelma menjadi dada ringkih Komar bin Syueb, menusuknya 
dengan tombak, sedikit saja untuk membuatnya tersadar ada sesuatu mengancam. Kini ia berharap bisa menusuk dada yang sesungguhnya, mengirimnya ke kerak neraka, dan meletup dalam kata-kata. (Kurniawan, 2004, p. 55)

Margio hate and vengeance to his father. He mad of what his father done to his mother. He tried to hold his anger to not to murdered his father. However, his anger and vengeance released to pig that being hunted. He beaten the pigs hardly as hard his father beaten his mother.

From the quotations above, it is explained that there is a causal connection happened in the story. The violence that usually happened in Margio's family affecting Margio's personality. $\mathrm{He}$ is aggressive and unruly which made pigs as his release of vengeance. As a result, the pattern of this causal connection is; 1) his father violated Nurraeni seen by Margio, his father violated Margio as well, 2) Margio is an object of violation, vent his vengeance or violation he received to pigs he has been hunted. Margio used to imagine his father while he beaten the pigs. This patterns is one of identical events as mention in the concept of frequency.

Another identical events found in the story is about how Margio is the one who lovable, family person, strong, powerful but not brave enough to use his strength against his father even though he had vengeance to his father. These characterizations always being told since the beginning of the story. It is lead to the mains story which is the murdered of
Anwar Sadat. The description of the characterization of Margio are;

1) Margio is strong and Powerful

Margio is strong young man who lived in small town. Since the beginning of the story, it is told that Margio is the strongest than his friends;

Di antara gerombolan pemburu yang hingga tahun-tahun terakhir masih dipimpin Mayor Sadrah, Margio bolehlah disebut jagoannya. Ia masih punya warisan luka di punggungnya disabet taring babi, namun semua kawannya tahu berapa babi menyerah diterjang tombaknya, sebelum diseret ke arah perangkap dan dijebak hiduphidup.(...)

Di antara perburuan yang penuh muslihat melawan binatang yang jelas tak ada otak itulah, Margio dikenal sebagai penggiring, dengan larinya yang tangguh dan tombaknya yang tanpa ampun. (...)

Tak banyak yang punya cukup nyali mengambil tugas sebagai penggiring, yang mesti berlari sama cepat di samping si babi, dan dengan cara itulah Margio dipuja. (Kurniawan, 2004, p. 7)

The quotation explained how Margio is the one who herding pigs bravely rather than others. He is the one who strong enough to handle the horde of pigs. The characterization on how strong and powerful of Margio is being told in the beginning of the story.

2) Margio is family person

The first quotation mentioned that Margio is strong and powerful young 
man. However, this quotation explained on how Margio is lovable and obedient to their parents. He never used his strength to bad thing. He wisely enough to control his strength.

Selama bertahun-tahun memimpin militer kota, tugas paling menyibukkannya adalah melerai perkelahian-perkelahian ini. Bahkan sejauh yang ia tahu, dalam perkelahian-perkelahian ini Margio tidaklah menonjol, meskipun semua orang tahu ketangguhannya. Ia anak pemurung yang tak betah di rumah, tapi sesungguhnya anak yang manis dan santun. Ia tak terlalu bodoh menyia-nyiakan kekuatan tubuhnya dalam perkelahian, dan sepanjang hari mengambil kerja serabutan untuk menyia-nyiakannya dalam bungkus rokok dan botol bir, tapi tetap saja ia anak manis meski pemurung. Semua orang tahu ia membenci ayahnya, dan semua yakin ia bisa menghabisinya, tapi sampai Komar bin Syueb mati ia tak pernah mencobanya sedikit pun. Ia sungguh tak banyak polah. Maka ketika mendengar Margio membunuh, bagaimanapun Mayor Sadrah masih belum memercayainya. (Kurniawan, 2004, p. 10)

From the quotation above, it is told that everybody knew that he could use his strength against his father but he did not. He respect his father and love his family. Therefore, no one's could believe that he is the one who killed Sadat.

Margio always spent his time to travel far away from home of his grandfather. This part is proved that Margio is family person.

Pada umur delapan tahun, Margio telah melakukan perjalanan itu seorang diri untuk pertama kali. Selepas itu ia akan mempergunakan setiap kesempatan untuk pergi ke sana, berjumpa kakeknya, tak peduli waktu perjalanan yang bisa merampok separuh harinya. Perjalanannya selalu merupakan saatsaat menyenangkan, dan setiap kali berkunjung ia akan membawa pulang setan dan pisang, atau sekeranjang durian, atau sekarung duku, yang pasti bikin senang Mameh, juga ibu dan ayahnya. (Kurniawan, 2004, pp. 41-42)

The quotation mentioned that Margio used to bring fruits to make his family happy. The goals of his pride is make his family happy. Therefore, the characterization of Margio is strong, powerful young man, loveable and family person. The characterization of Margio is being told since the end the story.

Therefore, no one believes that Margio is the one who killed Anwar Sadat. Another character mentioned that steal his own father chicken is the worst things that Margio ever did. "Mencuri ayam, itulah satu-satunya kelakukan jahil anak itu," kata Kyai Jahro. "Dan ayamayam itu milik ayahnya sendiri." (Kurniawan, 2004, p. 14). The quotation proved that how Margio is a good person and did not expect that he is the murderer. However, the murderer issues is another identical events that found in this story of Lelaki Harimau. The murderer issues 
found in several sections of the story, for example;

Senja ketika Margio membunuh Anwar Sadat, Kyai Jahro tengah masyuk dengan ikan-ikan di kolamnya, ditemani aroma asin yang terbang di antara batang kelapa, dan bunyi falseto laut, dan badai jinak merangkak di antara ganggang, dadap, dan semak lantana.(...)

(...) Dengan hidung tersengal-sengal, ia memberitahu mereka bahwa Margio telah membunuh Anwar Sadat. Ia mengatakannya dalam satu kesan agar Kyai Jahro bergegas untuk memimpin salat jenazah, sebab itulah salah satu tugasnya sepanjang tahun-tahun terakhir. (Kurniawan, 2004, pp. 1-3)

The quotation tells the same story which is the murder of Anwar Sadat by Margio. The story of the murder was mentioned in a different part but the events did not recur. The first quote is at the beginning of the novel where the story of the murder is used as the opening of the story. The murder event was raised as a time setting for other events which were then recounted, to then be followed by other characters' responses to the impact arising from the killing. In the second quote there is also a fleeting account of the murder and the opinions of other figures regarding the event.

Another part of murdered mention in another pages of the story, it is the detail how Margio murdered Anwar Sadat.

"Memang tidak," kata Ma Soma. "Bocah itu menggigit putus urat lehernya.".
Tak seorang pun mendengar seorang membunuh dengan cara yangs eprimitif itu. Ada dua belas pembunuhan yang mereka kenal sepanjang sepuluh tahun terahir seajarh kota, dan mereka mempergunakan golok atau pedang. Tak ada pistol, tak ada keris, apalagi gigitan. Ada ratusan kasus orang saling menggigit, terutama jika dua perempuan berduel, tapi tak satupun berahir dengan kematian. Berita itu jauh lebih menakjubkan, disebabkan pelaku dan korbannya. (...) (Kurniawan, 2004, p. 4)

(...) Pembunuhan itu, sebagaimana kemudian diyakini semua orang, terjadi tepat pada pukul empat sepuluh menit, sebab se puluh menit sebelumnya Margio masih bersama beberapa kawan dan sepuluh menit setelahnya, ia telah bersama mereka pula, dalam keadaannya yang mengejutkan. (Kurniawan, 2004, pp. 23-24)

It is explained on how Margio tears through Sadat's jugular with his own teeth. The murdered happened in the afternoon. From the quotation above, the society realized on how Margio is lovable, and family person is the one who murdered Sadat sadistically. Margio and Sadat are the good neighbors and known as a good person. However, this murdered events told identical as mentioned in the quotation below;

Di depannya, tanpa membuang tempo sebab dirinya sadar waktu bisa melenyapkan seluruh nyali, ia berkata kepada lelaki itu, "Aku tahu kau meniduri ibuku dan Marian anak 
kalian," katanya. Kalimat itu mengapung di antara mereka, Anwar Sadat pasi menatap wajahnya. Margio melanjutkan, "Kawinlah dengan ibuku, ia akan bahagia."

Tergagap Anwar Sadat menggeleng, dan dengan kata terpatah ia bergumam. "Tidak mungkin, kau lihat aku ada istri dan anak." Tatapan itu jelas mencela gagasan konyol Margio. Dan kalimat selanjutnya memberi penjelasan melimpah, "Lagi pula aku tak mencintai ibumu."

Itulah kala harimau di dalam tubuhnya keluar. Putih serupa angsa. (Kurniawan, 2004, pp. 189-190)

The quotation above explained the reason why Anwar Sadat did not want to marry Margio's mother. It is because Sadat did not want ruined his own family and did not love Margio's mother. Margio's mad when he heard that Sadat did not love his mother even though his mother and he had an intimate history. It made the female tiger inside Margio's body out and killed Sadat. This events is complete sequences of events of Anwar Sadat's murder. The murdered is one of the identical events as iterative narrative. It means that one events, one murder event occurs however the incident is told several times.

Based on the analysis above, it is seen that the plot of the story is quite hard to understand. The plot is jump backward and forward around the family history. However, the main story is quite simple and made the focus of the story stick to the main character. The concept of identical events from Genette is able to reveal the complexity of the plot that exists in the story of the Lelaki Harimau novel. By referring to the identical event, the murder by the main character, Margio, which then causes other characters to react to the murder and bring up other events related to the main character and their connections. From this discussion, it can be seen that the author's focus is on a character and his character description. The main focus is centered on the main character in the story of Lelaki Harimau, Margio. The reaction of the characters to the events of murder and causal relations is clearly seen in the series of events using this frequency concept.

Margio's known as polite, affectionate, wise, strong and powerful enough but managed to be well illustrated through a series of events in each chapter of his narrative. This portrayal of a good figure is able to make all society surprised by the killings committed by Margio. Even after carrying out the killings Margio calmly said that the tiger in his body was the one who killed Anwar Sadat. As attached in the following quote; "Bukan aku," kata Margio tenang dan tanpa dosa. Ada harimau dalam tubuhku”. (Kurniawan, 2004: 37). From the quote, the author clearly mentions Margio's calm and innocent feelings after killing Anwar Sadat. The construction of Margio's polite character was able to kill Anwar Sadat on the grounds of disrespecting his mother by refusing to marry her sadistically. But the calm depicted in the story, which the author deliberately wrote, made Margio's character a cold-blooded killer.

The structure of the story was construct with great precision. The 
element of the story such as the plot and characters are also written in long writing yet still has an element of strong connection with each other. The main character and other characters in the story of Lelaki Harimau are characters who are able to move the story dynamically with depictions of conflict and story motifs that make this novel a living story. Although the reader is invited to explore various other events related to the main character and the core event, which is murder, this complicated plot can be solved by the causal relationship of the event series brought by the characters. The detective story model presented by the author adds to the unique impression of this novel. Background drawings accumulate from the sequence of events from the quote are as real and bring the reader into the story of this murder.

The analysis found that the author's tendency in presenting storytelling techniques is a combination of mysticalrealist killing. The mystical element was revealed by the figure of a tiger who inhabited Margio's character by killing Anwar Sadat by only tearing his neck. A fairly detailed telling of a murder incident that is scattered in various chapters of the story with the interrelation between the character and his background blindly this story looks realist or real. Thus, the reading is centered on the reader's spirit by playing identical student movements that recur with the motive that has been in each chapter of the Tiger Man story. Therefore, the story of Lelaki Harimau is a story that contains psychological elements of the main character Margio with a mystical element.

\subsection{Characterization of Margio}

Based on the use of the frequency concept, it is found that there are some characterization that formed Margio as the main character of the story in Lelaki Harimau. Margio is known as loveable, family person, strong and powerful. The characterization is formed since his childhood. However this perfect characterization is ruined by the murdered committing by him against Anwar Sadat. The main focus on the characterization of Margio can make the stories is easy to understand. In focusing on his character, it can found how some important part of the story lead to the main story. Therefore, it can be found the meaning drawn from the story.

The meaning drawn from this story is disharmony in the family. In the analysis above, Margio has a loving and polite attitude towards parents, but the hatred of his father makes Margio behave unruly, naughty, and demanding. The discourse of how the naughty, hard and challenging character is a reflection of his family's disharmony. McCarthy (1990) explained in how abusive family formed the abusive child. This study found how abusive interaction family. He stated that abusive parents to his child formed a trauma and forces a child to made a defend against disappointment. As it is represented by Margio in the story of Lelaki Harimau.

Therefore, after knowing the reason Anwar Sadat did not love his mother, Margio felt his mother was not valued by Sadat. Anger that has been buried from the trauma and towards Sadat then overflowed with the murder of Anwar Sadat on the basis of Margio's bad attitude from the disharmony of his 
family. Margio's characterization which from the beginning was described as a wise, polite, merciful, and hard person turned into a cold-blooded killer.

The novel succeded in presenting the unhappy marriage and vengeance. It is covered with the villages vibes of Indonesian and combined with supranatural elements of 'white tiger' inside Margio's body. It can be seen the white tiger is kind of trauma that burried in Margio. Therefore, Margio explained that the tigers inside his body drove his actions sadistically. The actions is outcome of trauma that had been buried. It is when Margio's felt disappointed to Sadat that Sadat did not love and marry his mother. As a result, this actions is part on how the complexity of human relations in family issues that should be done in good communication through each member of family.

\section{CONCLUSION}

It is conclude that the used concept of frequency with identical events as the main references can answer the research question of the study. It is found that Margio has the strong characterization who can linked to the important part of the story of Lelaki Harimau. Margio known as lovable, family person, strong and powerful who is not strong brave enough to kill his father but Anwar Sadat sadistically. Therefore, all the perfect characterization that known by Margio's neighbor is ruined by the murdered. This family represent how the complexity of human relation in family life. Furthermore, this study expected to be a references for any researchers in the same focused of the study.

\section{REFERENCES}

Arianto, T., \& Simanjuntak, D. S. (2019).

Paradoxical Representation of

Female Narration in the Spirit of Mak Ungkai StoryNo Title. Journal BASIS, 6(2), 173-184. https://doi.org/https://doi.org/10.338 84/basisupb.v6i2.1413

Choiriah, Y. M. (2016). Struktur Dan Pergerakan Penceritaan Cerita Fantastik Novel Cantik Itu Luka, Lelaki Harimau, Dan Seperti Dendam, Rindu Harus Dibayar Tuntas Karya Eka Kurniawan. Skriptorium, 6(2) http://repository.unair.ac.id/id/eprint/ 55236

Gemilang, M. S. (2016). Psikologis

Tokoh Margio Dalam Novel

Lelaki Harimau Karya Eka

Kurniawan. Repository Unair.

Program Studi Sastra Indonesia.

Universitas Airlangga. Repository

Unair.

Genette, G. (1980). Narrative Discourse an Essay in Method. Translated by Jane E.Lewin. . Itacha. New York: Cornell University Press. .

Harususilo, Y. E. (2018). Edukasi, Kompas.com. Retrieved from Kompas.com: https://edukasi.kompas.com/read/ 2018/12/07/22212401/ekakurniawan-raih-penghargaansastra-internasional-dibelanda?page $=$ all 
Vol. 7 No.l April 2020

e-ISSN : 2406 - 9809 p-ISSN : 2527 - 8835

Kobis, D. C. (2019). A Comparative Study: Genetic Structuralism on Jane Eyre and the Great Gatsby. Jurnal BASIS, 6(1), 1-12. https://doi.org/https://doi.org/10.3 3884/basisupb.v6i1.1054

Kurniawan, E. (2004). Lelaki Harimau. Jakarta: PT. Gramedia Pustaka Utama.

McCarthy, J. B. (1990). Abusive Families and Character Formation. American Journal of Psychoanalysis, 50(2), 181-186. https://www.pepeb.org/document. php?id=AJP.050.0181A

Nugriyantoro, B. (2015). Teori Pengkajian Fiksi. Yogyakarta: Gadjah Mada University Press.
Oktavia, Y. (2015). Kecenderungan Penokohan dalam Novel Bumi Cinta Karya Habiburrahman El Shirazy. Journal BASIS, 2(1), 49-56. http://ejournal.upbatam.ac.id/index.p hp/basis/article/view/1037

Purwaningsih, E. (2010). Keluarga Dalam Mewujudkan Pendidikan Nilai Sebagai Upaya Mengatasi Degradasi Moral. Jurnal Pendidikan Sosiologi Dan Humaniora, 1(1), 43-56.

Retrieved from http://jurnal.untan.ac.id/index.php/ JPSH/article/view/379/382

Ratna, N. K. (2008). Teori, Metode, dan teknik Penelitian Sastra. Cetakan $I V$. Yogyakarta: Pustaka Pelajar. 